\title{
PHYSICAL MODEL EXPERIMENTS OF ORDU-GIRESUN AIRPORT, TURKEY
}

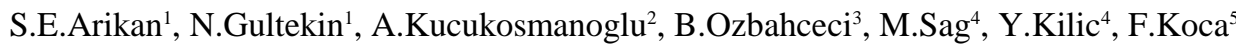 \\ Ordu-Giresun Airport, which has been constructed recently, being an example of the aviation sector of Turkish \\ transportation network, is a project having marine structural aspects due to the construction at the sea by filling and \\ in this workout physical model experiments of the project are evaluated. 3000-meters-long runway and the other \\ superstructures of the airport, the first example of construction of such a structure by filling in the sea in Turkey, is to \\ be protected by a breakwater of 7435 meters long. 'First Cross Section' has been prepared by using experimental \\ formulas and artificial neural network and 'Second Cross Section', being the alternative of the first one has been \\ planned. Yet, both cross sections have similar characteristics, they have berm heights in such a manner that 'First \\ Cross Section' enables the structure to be constructed from the sea, whereas 'Second Cross Section' makes it possible \\ from the land. Both cross sections are aimed to be evaluated in terms of stability, wave overtopping and economy \\ through the hydraulic model studies performed at the Hydraulics Laboratory of Turkish Ministry of Transportation, \\ Maritime Affairs and Communication. Starting from design stage (computation of design wave characteristics, \\ physical model experiment under different wave conditions on different structure alternatives) to construction stage \\ the engineering studies is presented with comparisons and discussions.
}

Keywords: airport, breakwater, physical modeling, stability, overtopping

\section{INTRODUCTION}

Along the 8300-km-long-coastline of Turkey there are 110 transportation port operation, 62 tourism coastal structures, 384 fishery coastal structures available, however, there has recently been constructed a coastal structure serving for aviation sector in Turkey for the first time; an airport constructed in the sea by filling. The location of the project area is shown in Figure 1.

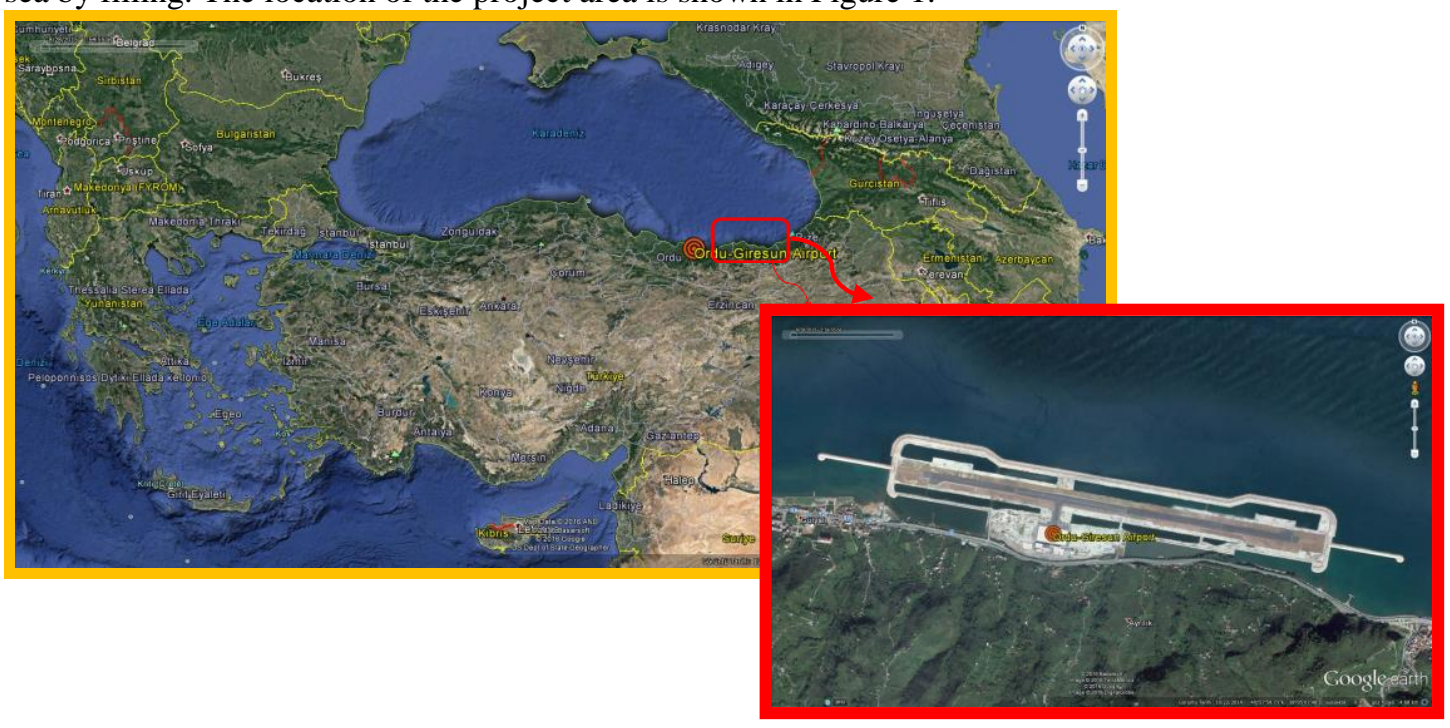

Figure 1. Ordu-Giresun airport project location $\left(40^{\circ} 57^{\prime} 54.20^{\prime \prime}\right.$ N $\left.38^{\circ} 4^{\prime} 50.26^{\prime \prime} \mathrm{E}\right)$

3000-meters-long runway and the other superstructures of the airport are to be protected by 7435 meter-long breakwater. Physical model experiments have been performed to investigate both safe in terms of stability and wave overtopping and meantime economic breakwater protecting the airport. The general layout of the airport is shown in Figure 2 and parts of the breakwater considered in physical modeling tests are shown as $\mathrm{A}, \mathrm{B}$ and $\mathrm{C}$.

\footnotetext{
${ }^{1}$ Ministry of Transport, Maritime Affairs and Communications, General Directorate of Infrastructure Investment, Head of Research Department, Ankara, Turkey

${ }^{2}$ Department of Civil Engineering, Mehmet Akif Ersoy University, Burdur,Turkey

${ }^{3}$ Department of Civil Engineering, Izmir Institute of Technology, Izmir, Turkey

${ }^{4}$ Ministry of Transport, Maritime Affairs and Communications, General Directorate of Infrastructure Investment, Head of Harbor Project, Ankara, Turkey

${ }^{5}$ Ministry of Transport, Maritime Affairs and Communications, General Directorate of Infrastructure Investment, Head of Railways Project, Ankara, Turkey
} 


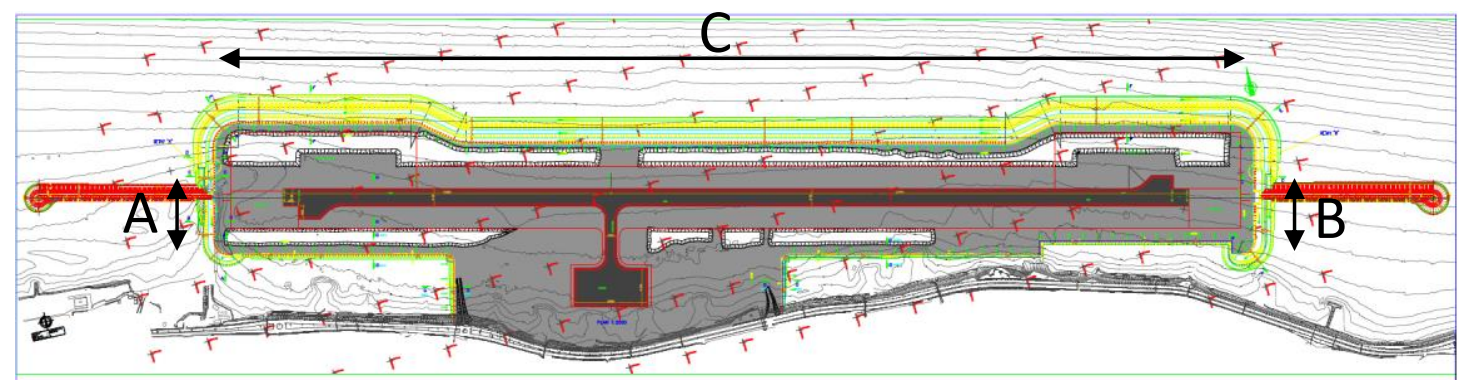

Figure 2. Ordu-Giresun airport general layout and parts of the breakwater

\section{Wind and Wave Climate for the Project Area}

As it is known, since the wave force is the most important factor of marine structures such as breakwaters, determination of the design wave condition takes much importance. For the design of airport breakwater, 100 years of return period wave condition have been taken into account. According to the extreme wave statistics of 'Wind and Deep Water Wave Atlas of Turkish Coasts' (Ozhan and Abdalla, 2002) (Figure 3) deep water wave parameter of $H_{s}=7.6 \mathrm{~m} \mathrm{~T}_{m}=12 \mathrm{~s}$ value is seen for the location of $41.25^{\circ} \mathrm{N} 38.00^{\circ} \mathrm{E}$.

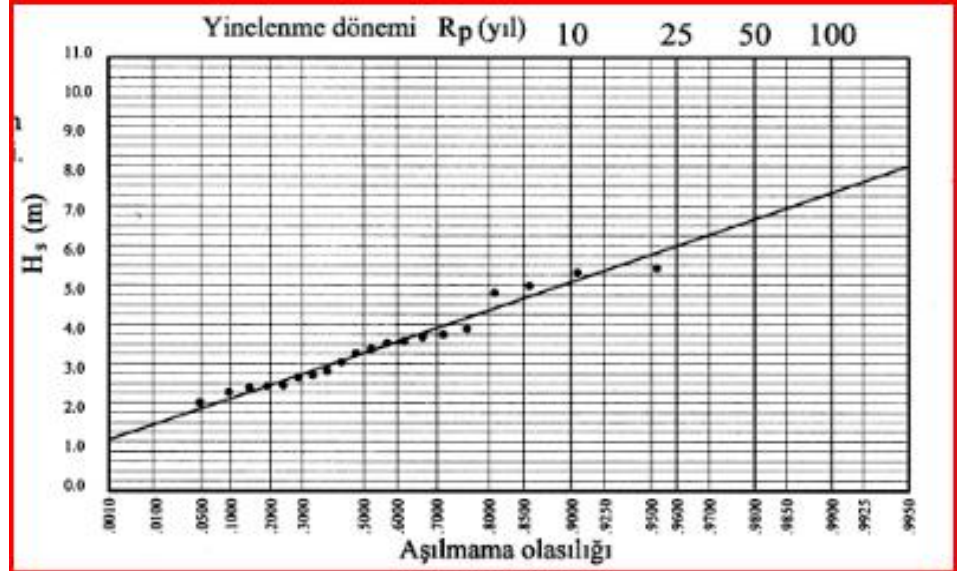

Figure 3. Extreme wave statistics for $41.25^{\circ} \mathrm{N} / 38.00^{\circ} \mathrm{E}$ in Wave Atlas (Ozhan and Abdalla, 2002)

Moreover, wind and wave climate studies have been performed by using ECMWF wind fields data. This analysis have supplied the deep water wave parameters shown in Table 1 together with $90 \%$ confidence intervals, (Yuksel Project International A.S, 2011).

\begin{tabular}{|c|c|c|c|c|c|c|}
\hline \multicolumn{7}{|c|}{ Table 1. Deep Water Design Wave Parameters } \\
\hline \multirow{2}{*}{$\begin{array}{c}\text { ECMWF } \\
41.50^{\circ} \mathrm{N}-38.20^{\circ} \mathrm{E}\end{array}$} & \multicolumn{6}{|c|}{ Return Period (years) } \\
\hline & 5 & 10 & 20 & 50 & 100 & 200 \\
\hline $\begin{array}{c}\text { Deep Water } \\
\text { Significant Wave } \\
\text { Height, } H_{S}(m)\end{array}$ & $5.27 \pm 0.42$ & $5.78 \pm 0.56$ & $6.27 \pm 0.70$ & $6.90 \pm 0.90$ & $7.37 \pm 1.05$ & $7.84 \pm 1.20$ \\
\hline $\begin{array}{c}\text { Deep Water } \\
\text { Significant Wave } \\
\text { Period, } T(s)\end{array}$ & 9.31 & 9.56 & 9.96 & 10.45 & 10.80 & 11.14 \\
\hline
\end{tabular}

Wave calculations and model tests normally have been conducted at mean sea level (MSW) condition but one may expect water level increases during 100-years design period so considering the global warming $(0.80 \mathrm{~m})$, wind setup and barometric effects $(0.12 \mathrm{~m})$, tidal and seasonal changes $(0.20 \mathrm{~m})$, totally $+1.12 \mathrm{~m}$ of sea level rise is estimated and it has also been taken into account in the model tests as high water level (HWL). 
It is necessary to find out the wave parameters acting on the breakwater structures so the wave data have been calculated in front of the structure through wave transformation numerical simulation and given in Table 2 for the A, B and C parts of the breakwater shown in Figure 2, (Yuksel Project International A.S, 2011).

\begin{tabular}{|c|c|c|c|c|c|c|}
\hline \multirow[b]{3}{*}{$\begin{array}{l}\text { Return Period } \\
\text { (years) }\end{array}$} & \multirow{2}{*}{\multicolumn{2}{|c|}{$\begin{array}{c}\text { A \& B Parts } \\
\text { HWL (ds }=6 m)\end{array}$}} & \multicolumn{4}{|c|}{ C Part } \\
\hline & & & \multicolumn{2}{|c|}{$\mathrm{MWL}(\mathrm{ds}=10.67 \mathrm{~m})$} & \multicolumn{2}{|c|}{$\mathrm{HWL}(\mathrm{ds}=11.79 \mathrm{~m})$} \\
\hline & $\mathrm{Hs}(\mathrm{m})$ & $\operatorname{Tm}(\mathrm{s})$ & $\mathrm{Hs}(\mathrm{m})$ & $\operatorname{Tm}(\mathrm{s})$ & $\mathrm{Hs}(\mathrm{m})$ & $\operatorname{Tm}(\mathrm{s})$ \\
\hline 5 & 2.52 & 6.93 & 2.96 & 6.84 & 3.04 & 6.93 \\
\hline 10 & 3.33 & 8.00 & 4.18 & 7.97 & 4.22 & 8.00 \\
\hline 20 & 4.06 & 9.40 & 5.26 & 9.36 & 5.35 & 9.40 \\
\hline 50 & 4.62 & 10.54 & 5.91 & 10.50 & 6.07 & 10.54 \\
\hline 100 & 5.29 & 11.93 & 6.80 & 11.99 & 7.25 & 11.93 \\
\hline
\end{tabular}

\section{Physical Modeling of the Project}

Bathymetrical measurements showed that the sea bed slope of $1 / 50$ coming from deep sea increases to $1 / 20$ from the $20 \mathrm{~m}$ depth location and the bathymetrical situation has been produced in the model as shown in Figure 4.

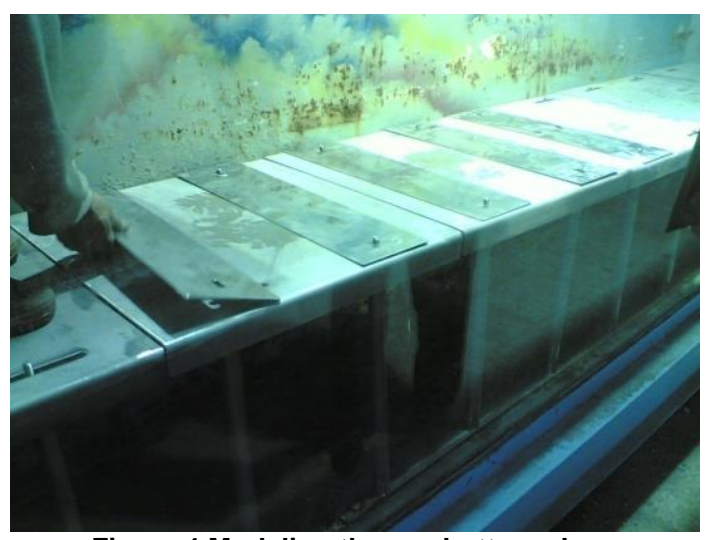

Figure 4 Modeling the sea bottom slope

Considering the capacity of the wave channel and wave generator, it appeared that the model scale of $1 / 35$ have been decided to be applicable for the modeling. Stone categories have been determined by using Froude similarity and the unit density difference of model unit stones and prototype rocks also considered in determining the model stone weights. Wave parameters calculated in Table 2 have been produced in the wave channel at the model scale. Incoming and reflected waves have been separated by absorption mode, so only the incoming waves, like in the nature, have been taken into account. Every wave set has been applied as containing 1000 irregular waves with Bretschneider-Mitsuyasu spectrum. Through the cumulative application of 5, 10, 20, 50, 100 years return period waves, the storm events, as if in the nature, starting from small waves, continuing to increase and reaching the highest value in 90 percent confidence interval of the design wave of 100 years return period have been simulated.

The fact that the breakwater remains stable throughout its life time and supplies secure area at the land side is of upmost goal so the stability of the cross sections of breakwaters has been evaluated in detail. Starting from small waves, the displaced units are counted and at the end of the wave set the cumulative damage is considered. It is necessary that the damage ratio is less than 5\% to regard a cross section as stable.

Another parameter that should be evaluated during the model tests is wave overtopping. Wave overtopping may be harmful for the rear side of the structure, both for the structure itself and also 
equipments, roads, other structures etc., if any. In the scope of this project, the breakwater is to protect an airport structure and a service road is planned $8 \mathrm{~m}$ behind the breakwater, thus wave overtopping has been investigated whether it causes a risk or not.

In consequence of a research project, namely CLASH, contributing many scientists an overtopping manual for coastal structures have been published and the results have entered into the specifications such as CIRIA CUR Rock Manual. Considering the values available in these publications, maximum 10 $\mathrm{lt} / \mathrm{s} / \mathrm{m}$ overtopping discharge value have been decided to be allowable by related departments. Wave overtopping limits are available not only for average wave overtopping $(1 \mathrm{t} / \mathrm{s} / \mathrm{m})$ but also maximum overtopping for individual waves $\mathrm{V}_{\max }(\mathrm{lt} / \mathrm{m})$ because sometimes when total overtopped water amount divided by storm duration to find the average overtopping discharge may be small, however one individual massive overtopping might be harmful so measurements have been taken to find $\mathrm{V}_{\max }$ during some of the experiments.

\section{Modelled Breakwater Cross Sections}

By using experimental formula's and artificial neural network, preliminary cross-sections have been prepared for the parts, shown as A,B and C in Figure 2 to start with the model tests. A \& B parts belong to until Km:0+350 location of the breakwater and up to $-5.0 \mathrm{~m}$ water depth. The cross section projected for these parts is called as 'Starting section'. For the C part of the breakwater (Km:0+546 - 3+978), two types of cross section alternatives have been considered, first is cross section type having berm/(s) elevation of which is / (are) underwater (- elevations), second is of type, berm of which is at + elevations. First type of cross sections are prepared by targeting that the construction would be materialized from sea, whereas second type ones are intended for land side construction.

\section{Starting Section}

Empirically provided cross section for A\&B parts of the breakwater consists of 6-8 tons of rocks on $1 / 3$ slope at armour layer, berm with 8-10 Ton Stones having the top elevation of $-1.0 \mathrm{~m}$, crest elevation at $+4.50 \mathrm{~m}$ and is shown in Figure 5 .

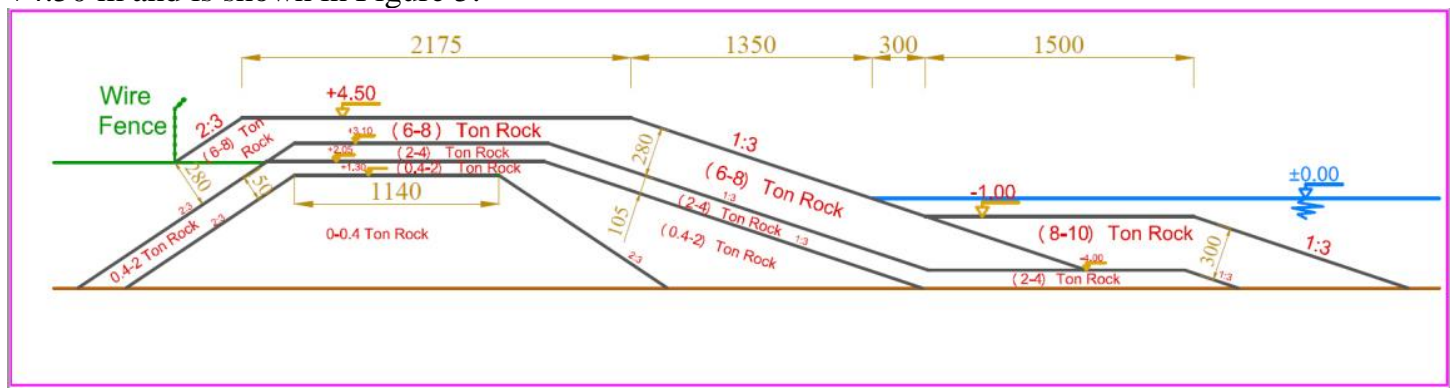

Figure 5 Starting Section (A\&B Parts of the breakwater)

Model tests have shown that the cross section for this part have been seen stable with armor layer damage ratio of less than $1 \%$. The overtopping discharge has been obtained as seen in Figure 6, reaching maximum $5 \mathrm{lt} / \mathrm{s} / \mathrm{m}$ value so it can be said that the cross section is also acceptable in terms of overtopping.

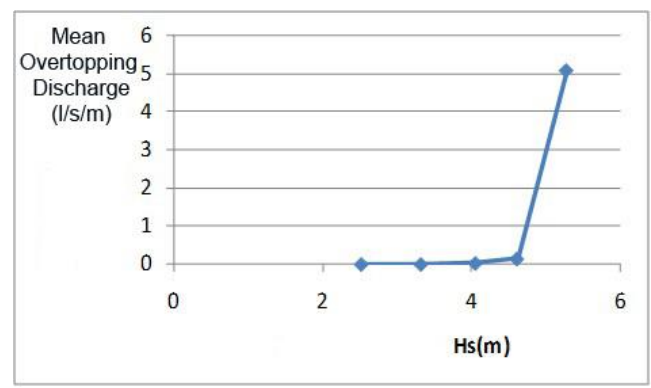

Figure 6 Measured overtopping discharges for 'Starting Section' 


\section{First (Type) Cross Sections}

Empirically prepared cross section for $\mathrm{C}$ part of the breakwater, where the wave action is most effective, consists of 6-8 tons of rocks on 1/3 slope at armour layer, first berm with 8-10 Ton Stones having the top elevation of $-1.0 \mathrm{~m}$, second berm with 6-8 Ton Stones having the top elevation of $-5.0 \mathrm{~m}$, 10-12 tons of stones at the toe, crest elevation of the breakwater structure at $+6.70 \mathrm{~m}$ and is shown in Figure 7. Figure 8 shows the placement of the breakwater model in wave the channel.

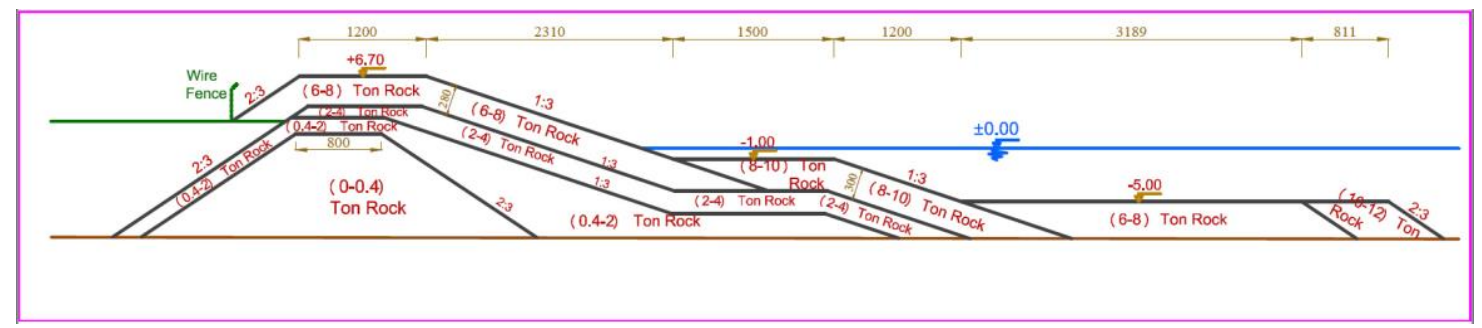

Figure 7 First Cross Section having underwater berms

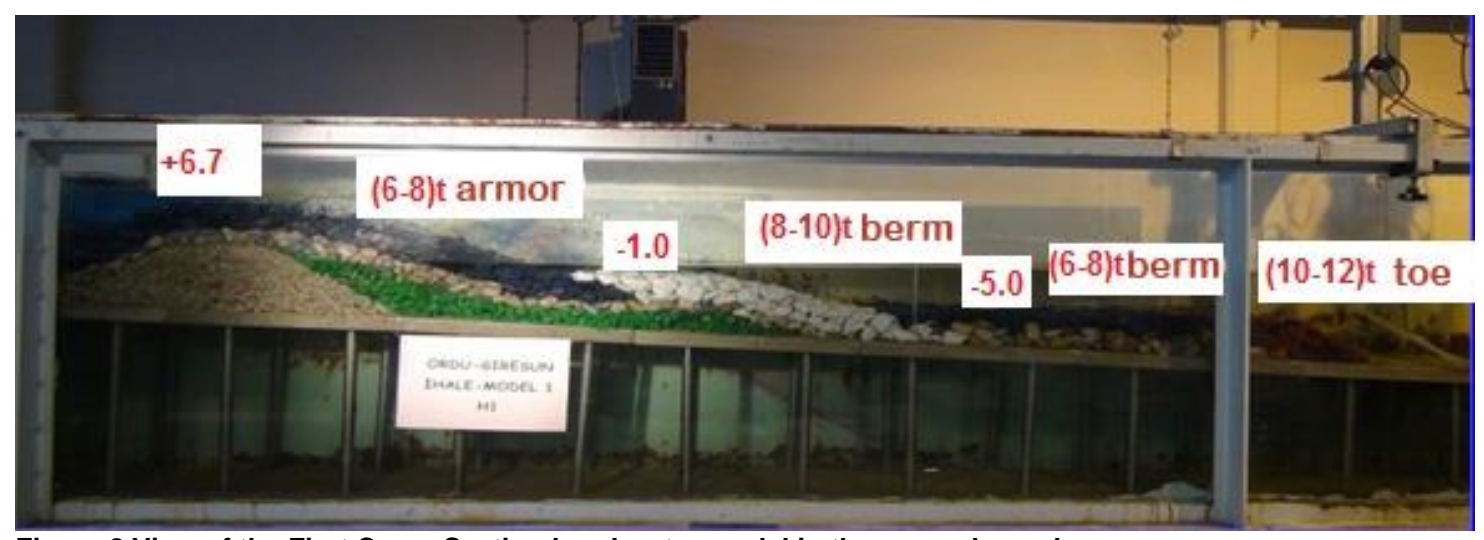

Figure 8 View of the First Cross Section breakwater model in the wave channel

Model tests proved that the cross section given in Figure 7 remains stable both in MWL and HWL and at all wave conditions. Moreover the wave overtopping discharge was measured within the accepted allowable limit. At the next stage, several more alternatives have been produced and tested to optimize the cross section intending to provide more economical solution together with allowable stability and overtopping values. The other variants of the First Cross Section, containing some changes at berm width, armor categories, slope, toe and crest elevation values are given in Figures 9-13.
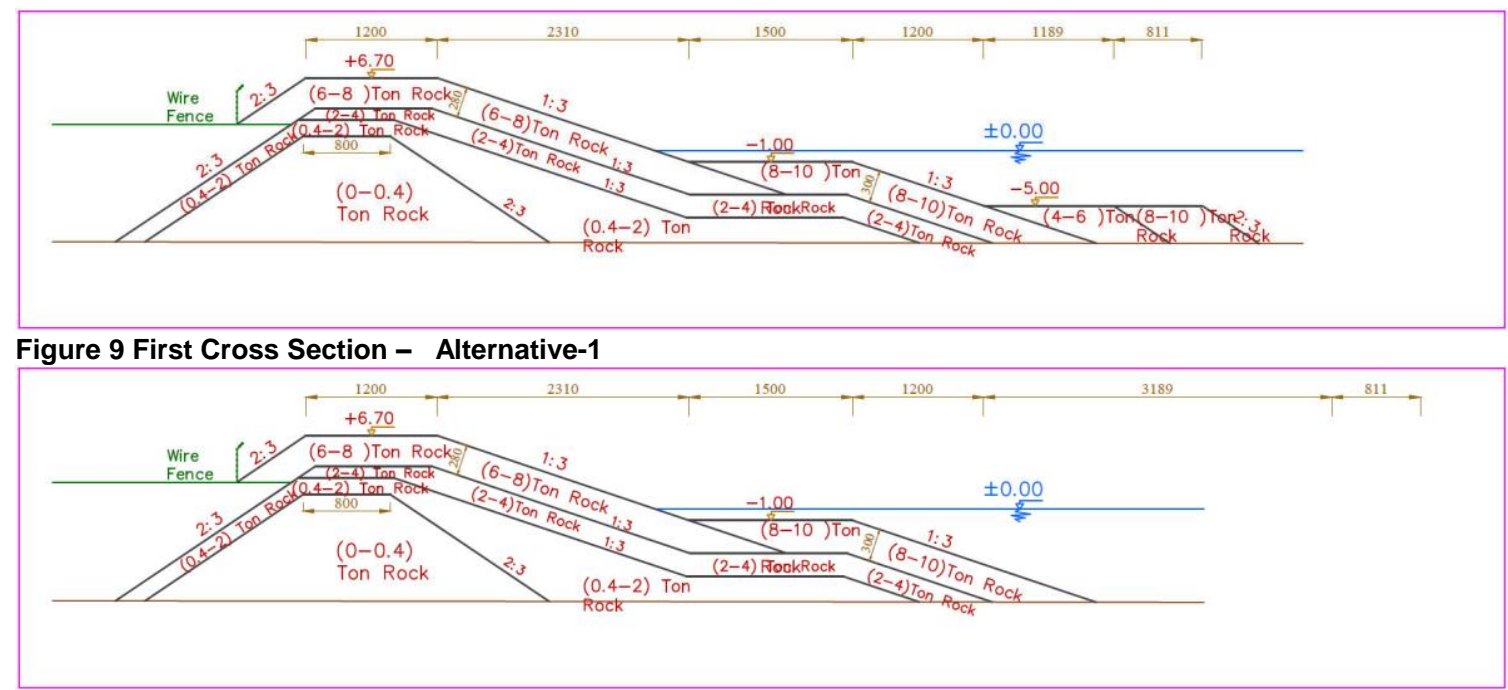

Figure 10 First Cross Section - Alternative-2 

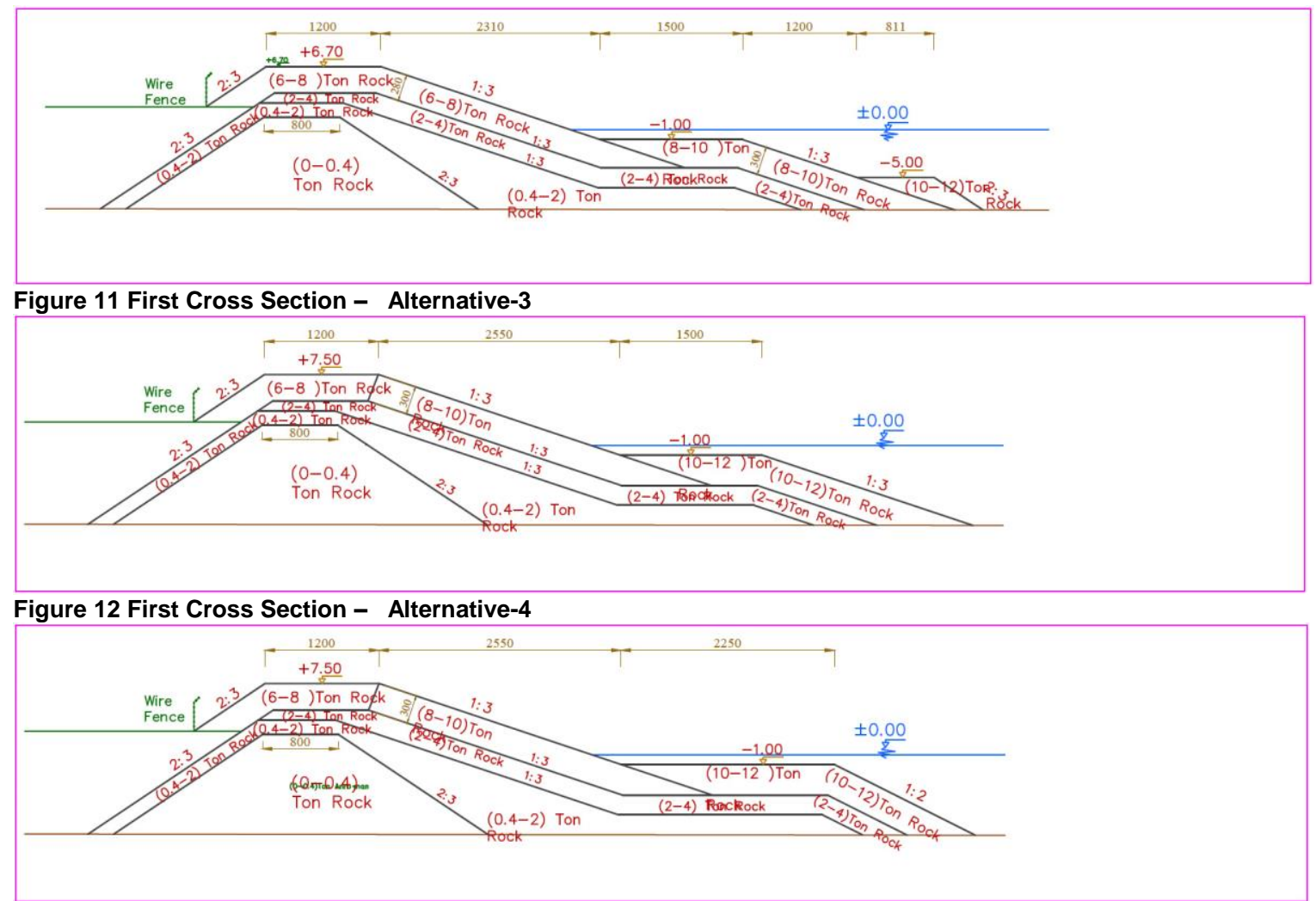

Figure 13 First Cross Section - Alternative-5

After the First Cross Section alternatives shown through Figure 7-13 have been tested under all wave conditions, cumulative damage ratios obtained at the armor layer and berm part and also measured overtopping discharges at HWL conditions are summarized in Table 3 together with the differences of alternative cross sections.

Table 3 Summary of the modeled First Cross Sections and test results (Damage ratios \& wave overtopping discharges)

\begin{tabular}{|c|c|c|c|c|c|c|c|c|c|}
\hline \multirow{3}{*}{$\begin{array}{l}\text { First Cross Section } \\
\text { Alternatives } \\
\text { First Cross Section } \\
\text { (FCS) }\end{array}$} & \multirow{3}{*}{$\begin{array}{c}\text { Crest } \\
\text { Height } \\
\text { (m) } \\
+6.7\end{array}$} & \multirow{3}{*}{$\begin{array}{c}\begin{array}{c}\text { Armor } \\
\text { Layer } \\
\text { (ton) }\end{array} \\
(6-8)\end{array}$} & \multicolumn{2}{|c|}{$(-1)$ m Berm } & $\begin{array}{c}(-5) \mathrm{m} \text { Berm - } \\
\text { kategori }\end{array}$ & \multirow[b]{2}{*}{$\begin{array}{l}\text { Toe Category } \\
\text { (ton) }\end{array}$} & \multirow{3}{*}{$\begin{array}{c}\text { Armor Layer } \\
\text { Damage (\%) } \\
0.00\end{array}$} & \multirow{3}{*}{$\begin{array}{c}(-1) \mathrm{m} \text { Berm } \\
\text { Damage } \\
(\%) \\
1.00\end{array}$} & \multirow{3}{*}{$\begin{array}{l}\text { Overtopping } \\
(1 / \mathrm{s} / \mathrm{m}) \\
4.29\end{array}$} \\
\hline & & & $\begin{array}{c}\text { Category (to } \\
\text { Width (m) } \\
\text { Slope }\end{array}$ & & $\begin{array}{c}\text { Category (ton) } \\
\text { / Width }(\mathrm{m})\end{array}$ & & & & \\
\hline & & & $(8-10) \quad 15$ & $1 / 3$ & $(6-8) \quad 40$ & $(10-12)$ & & & \\
\hline FCS-Alternative-1 & +6.7 & $(6-8)$ & $(8-10) \quad 15$ & $1 / 3$ & $(4-6) \quad 20$ & $(8-10)$ & 0.33 & 2.95 & 6.83 \\
\hline FCS-Alternative-2 & +6.7 & $(6-8)$ & $(8-10) \quad 15$ & $1 / 3$ & No & No & 1.33 & 6.74 & 13.07 \\
\hline FCS-Alternative-3 & +6.7 & $(6-8)$ & $(8-10) \quad 15$ & $1 / 3$ & No & $(10-12)$ & 0.33 & 4.44 & 12.60 \\
\hline FCS-Alternative-4 & +7.5 & $(8-10)$ & $(10-12) \quad 15$ & $1 / 3$ & No & No & 0.00 & 5.40 & 3.18 \\
\hline FCS-Alternative-5 & +7.5 & $(8-10)$ & $(10-12) 22.5$ & $1 / 2$ & No & No & 0.10 & 4.20 & 3.15 \\
\hline
\end{tabular}

Among the First (type) Cross Section alternatives, Alternative 4 and Alternative 5 can be commented as safe in terms of stability and overtopping and also more economical than the other alternatives. Only for Alternative 4, overtopped water amount of every individual wave has been measured to find out maximum individual wave overtopping Vmax and it was obtained as Vmax $=61251 \mathrm{t} / \mathrm{m}$.

\section{Second (Type) Cross Sections}

The important difference between the Second cross sections and the First ones, although they are similar to each other, first berm increased to $(+1) \mathrm{m}$ elevation in the Second cross section to enable the construction from land. The cross section consists of 6-8 tons of rocks on 1/3 slope at armor layer, first berm with 10-12 Ton Stones having the top elevation of $+1.0 \mathrm{~m}$ ( $15 \mathrm{~m}$ wide), second berm with 8-10 
Ton Stones having the top elevation of $-5.0 \mathrm{~m}$ (40 m wide), 10-12 tons of stones at the toe, crest elevation of the breakwater structure at $+6.70 \mathrm{~m}$ and is shown in Figure 14. Figure 15 shows the placement of the breakwater model in wave the channel.

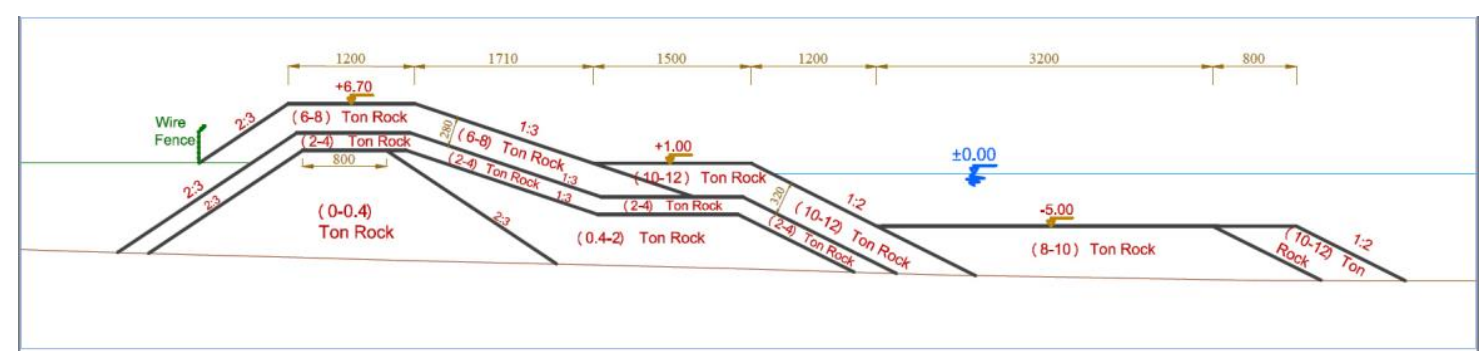

Figure 14 Second Cross Section having berm at (+) elevation

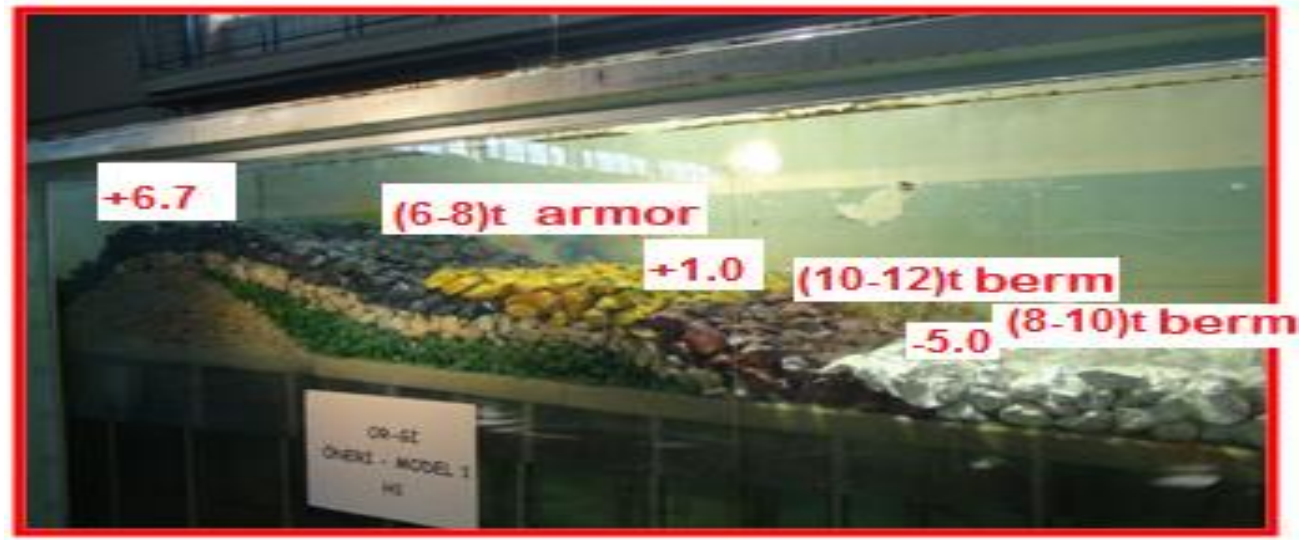

Figure 15 View of the Second CrossSection breakwater model in the wave channel

Some more alternatives also have been produced and tested to optimize the cross section aiming to provide more economical solution together with allowable stability and overtopping values. The other variants of the Second Cross Section, containing some changes at berm width, armor categories, slope, toe and crest elevation values are given in Figures 16-21.

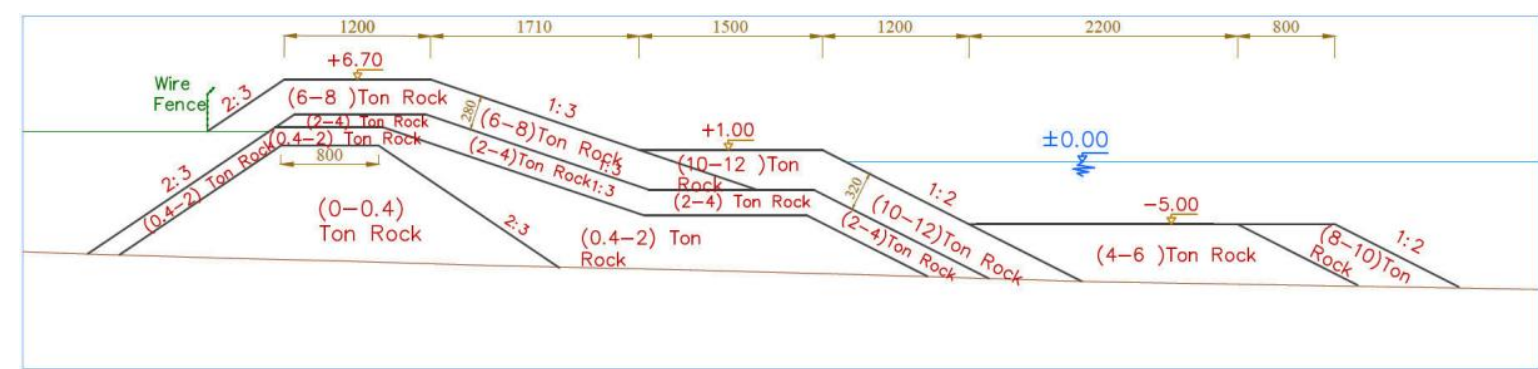

Figure 16 Second Cross Section - Alternative-1

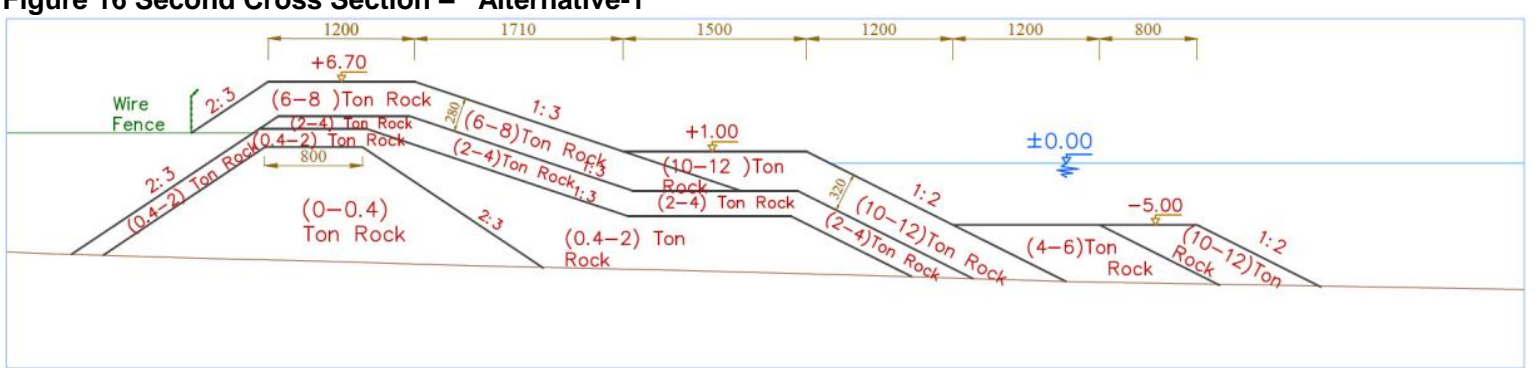

Figure 17 Second Cross Section - Alternative-2 


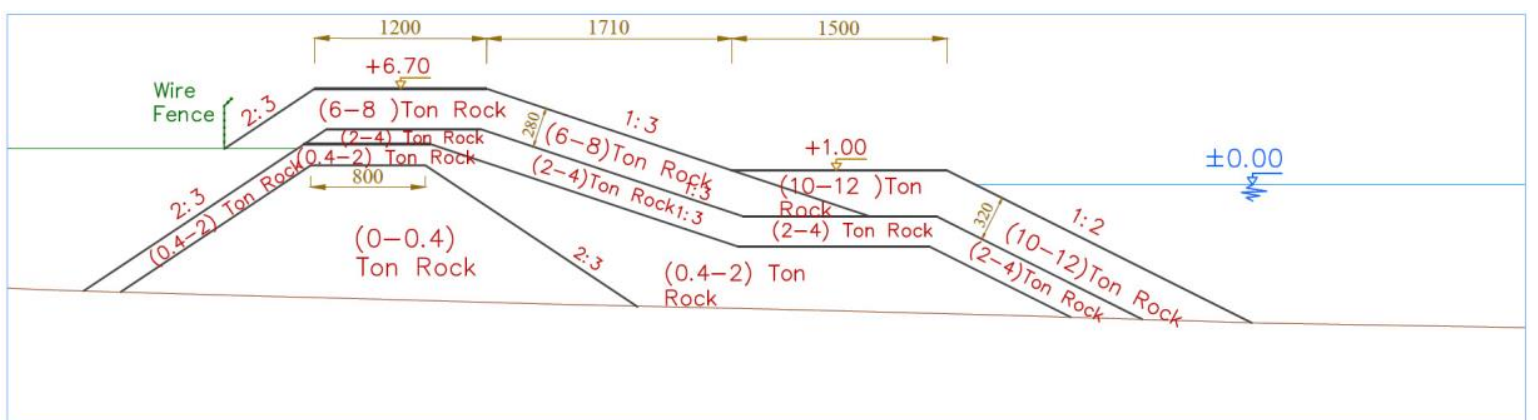

Figure 18 Second Cross Section - Alternative-3

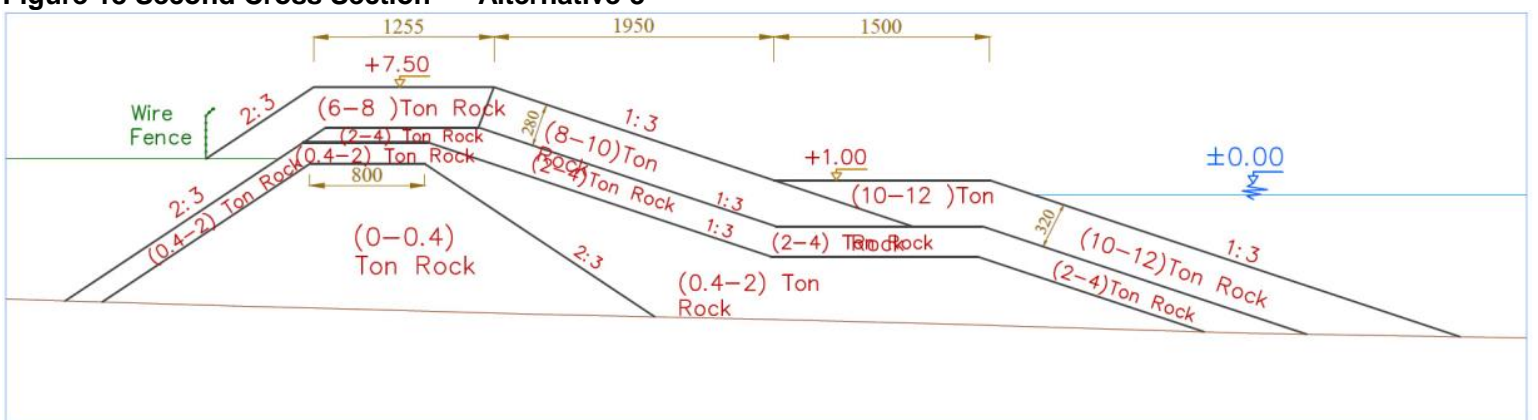

Figure 19 Second Cross Section - Alternative-4

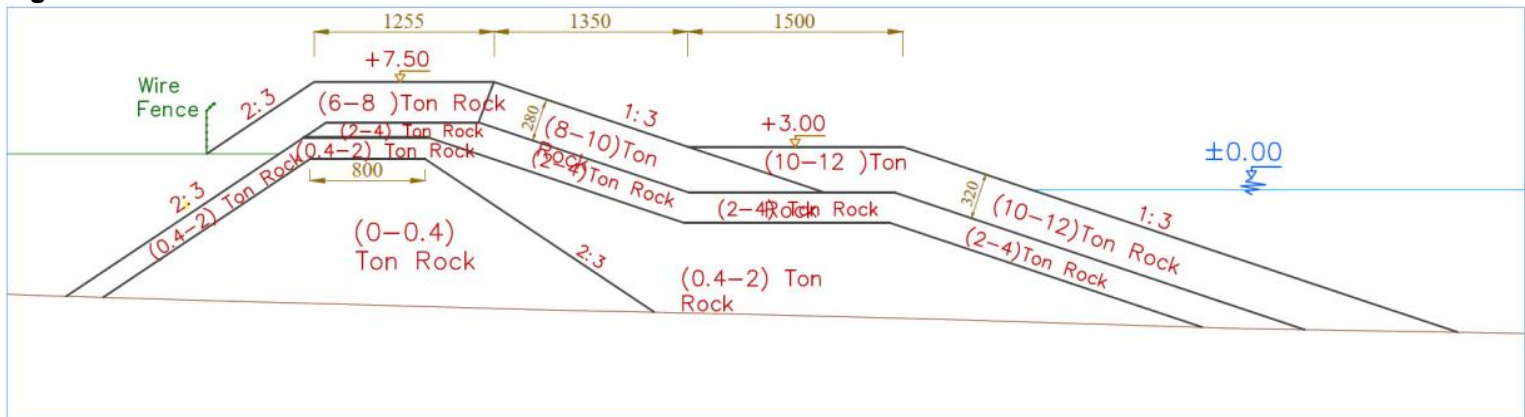

Figure 20 Second Cross Section - Alternative-5

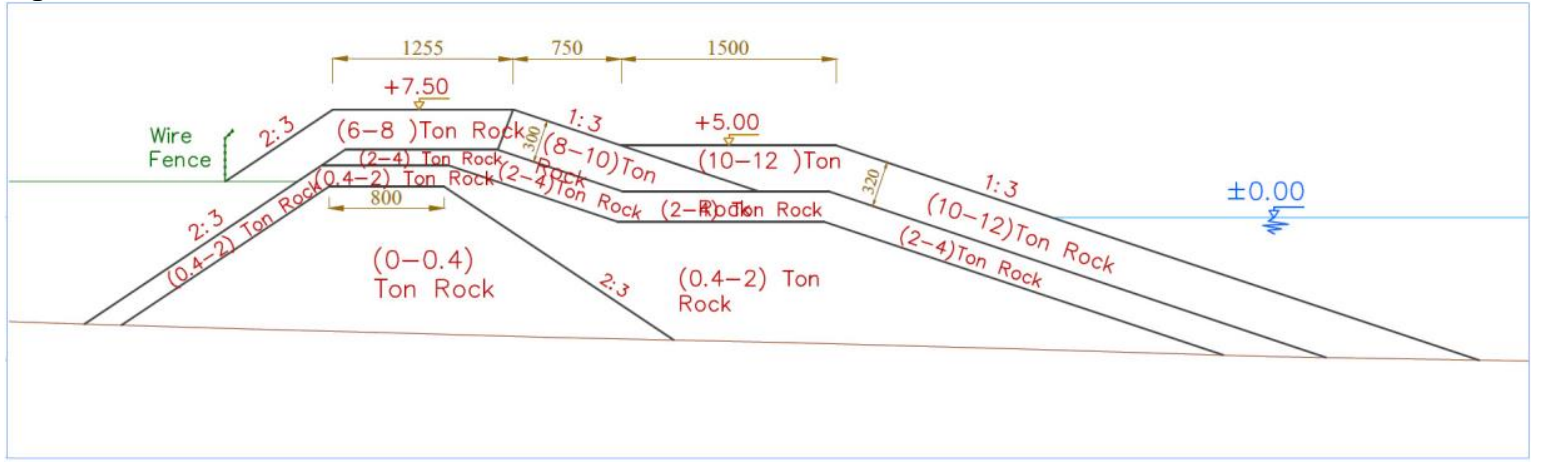

Figure 21 Second Cross Section - Alternative-6

After the Second Cross Section alternatives shown through Figure 14-21 have been tested under all wave conditions, cumulative damage ratios obtained at the armor layer and berm part and also measured overtopping discharges at HWL conditions are summarized in Table 4 together with the differences of alternative cross sections. 
Table 4 Summary of the modeled Second Cross Sections and test results (Damage ratios \& wave overtopping discharges)

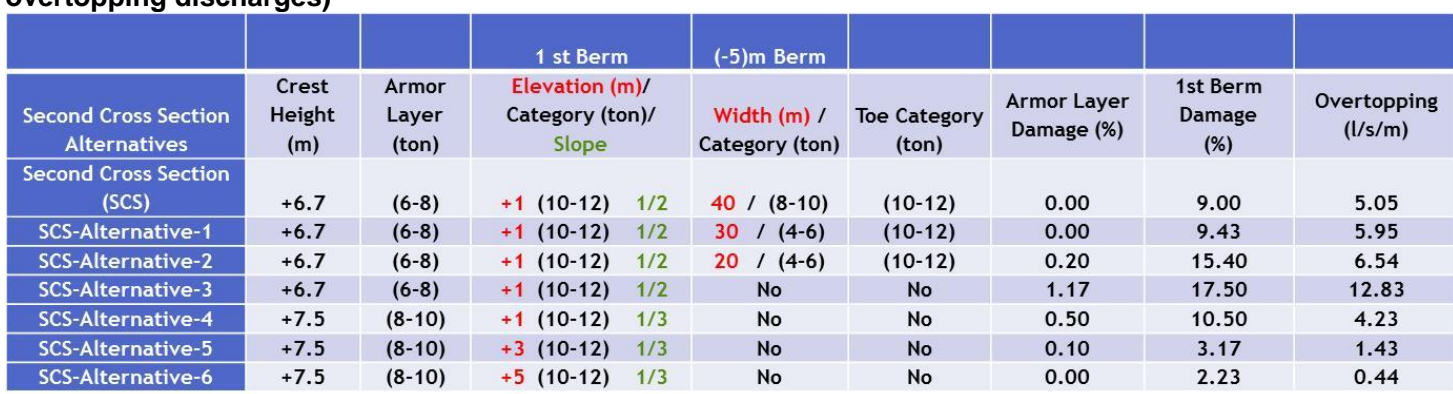

Among the Second (type) Cross Section alternatives, Alternative 5 and Alternative 6 can be commented as safe in terms of stability and overtopping but Alternative 5 appears to be more economical solution.

\section{CONCLUSIONS}

* For the First Cross Section Alternatives;

$>$ If the construction is decided to be made from sea, Alternative 4 and Alternative 5 can be regarded as stable and economical solution.

* For the Second Cross Section Alternatives;

$>$ If the first berm is to be constructed at the elevation of $(+1) \mathrm{m}$, it would be favorable to make a second berm at the elevation of $(-5) \mathrm{m}$, having at least 30 meters width.

$>$ First berm at $(+1)$ m elevation leads to the most unfavorable condition, causing the berm height at about water level especially at HWL condition.

$>$ It has been determined that the damage decreases as going away from the watel level.

$>$ It has been observed that increasing the first berm elevation to $(+3) \mathrm{m}$ affects the stability and overtopping positively.

$>$ If the first berm is wanted to be constructed at $(+)$ elevations, it becomes safe in terms of stability and overtopping without any second berm on the condition that its elevation is at least $(+3) \mathrm{m}$.

$>$ If the construction is decided to be made from land, Alternatif- 5 and Alternative- 6 can be regarded as stable and Alternative- 5 is more economical.

- Modeled cross sections represent the trunk section; bigger category armor usage is recommended for the armor layer and berms of the round heads.

- Wave overtopping has been observed to affect $20 \mathrm{~m}$ wide area from the crest to the behind so precautions should be taken for the vehicle and pedestrian traffic in the service road during storm times.

-Finally, Ordu-Giresun Airport Project of Turkish Ministry of Transportation, Maritime Affairs and Communication came true with 'Second Cross Section Alternative-5 and it has been in operation since May, 2015 (Figure 22).

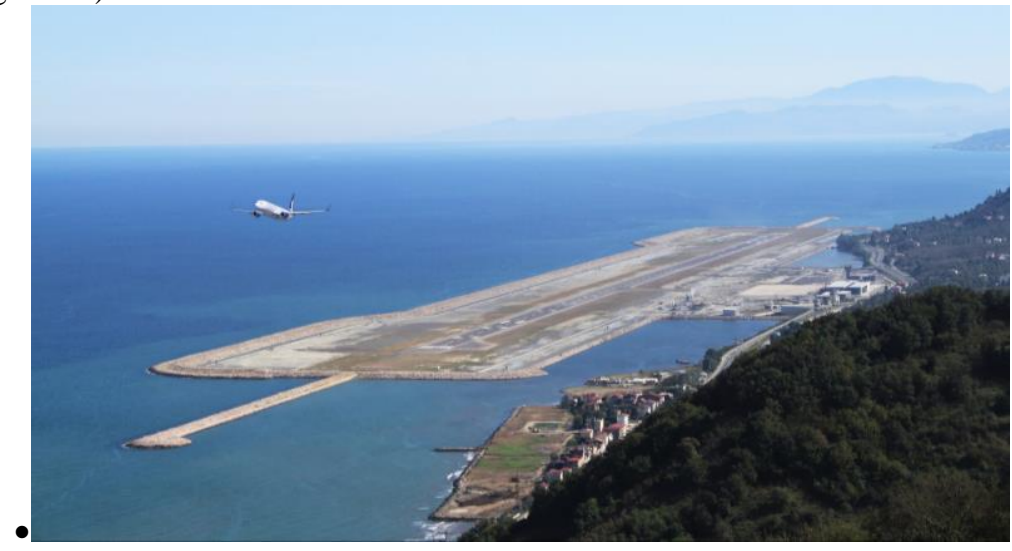

-Figure 22 Completion of Airport Construction with 'Second Cross Section Alternative-5' and Starting the Operation 


\section{APPENDIX}

Photos of the breakwater cross section alternatives taken before and after the experiment are presented below.

(a)
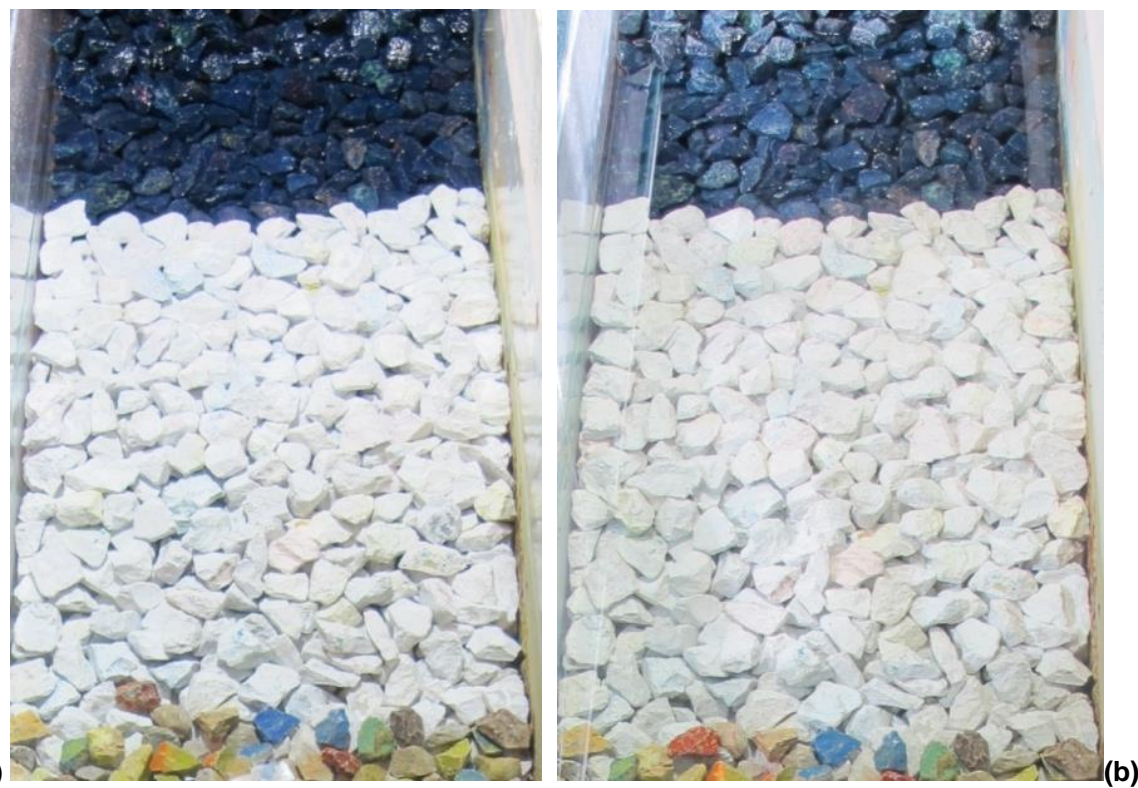

Figure A.1 (a) Before, (b) After the experiment wave set for Starting Section (A\&B Parts)
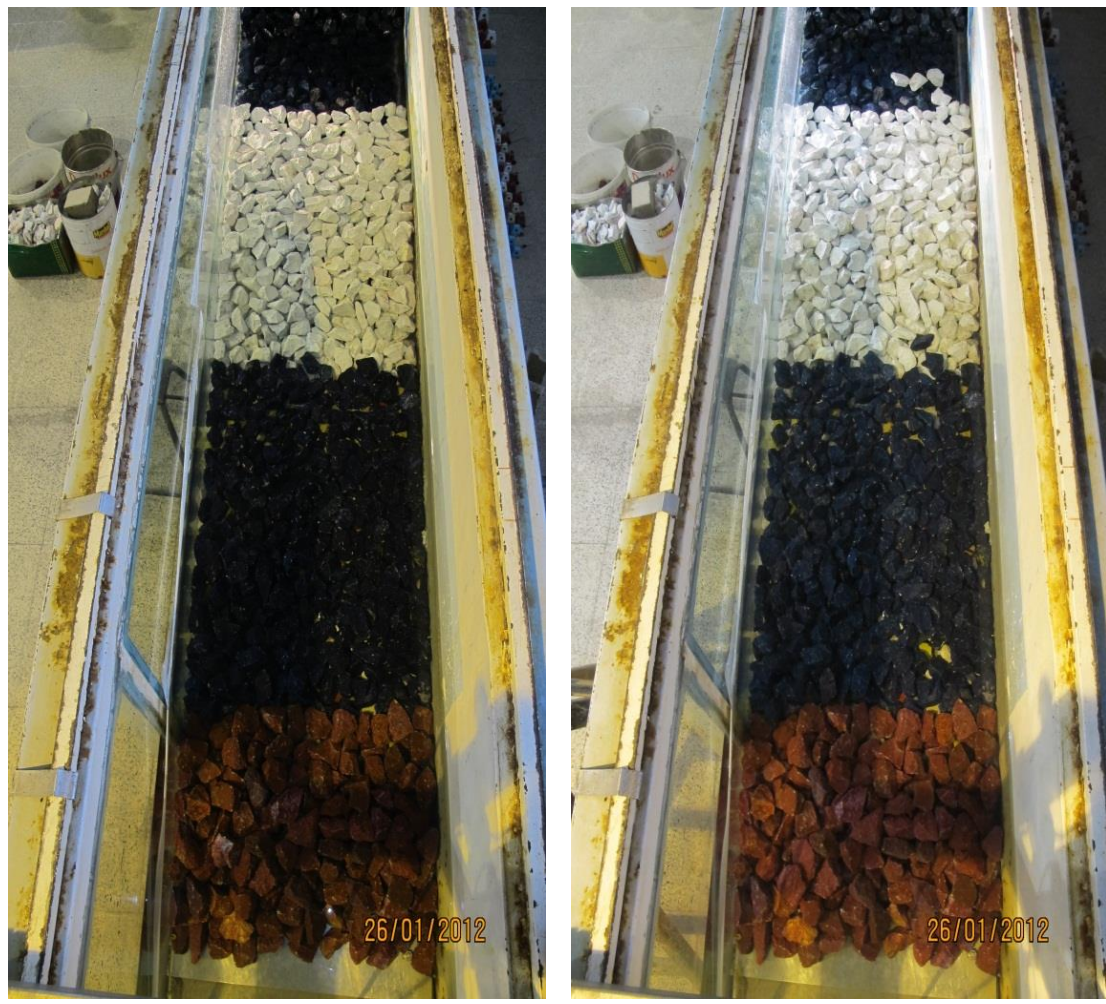

(b)

Figure A.2 (a) Before, (b) After the experiment wave set for the First Cross Section (C Part) 
(a)
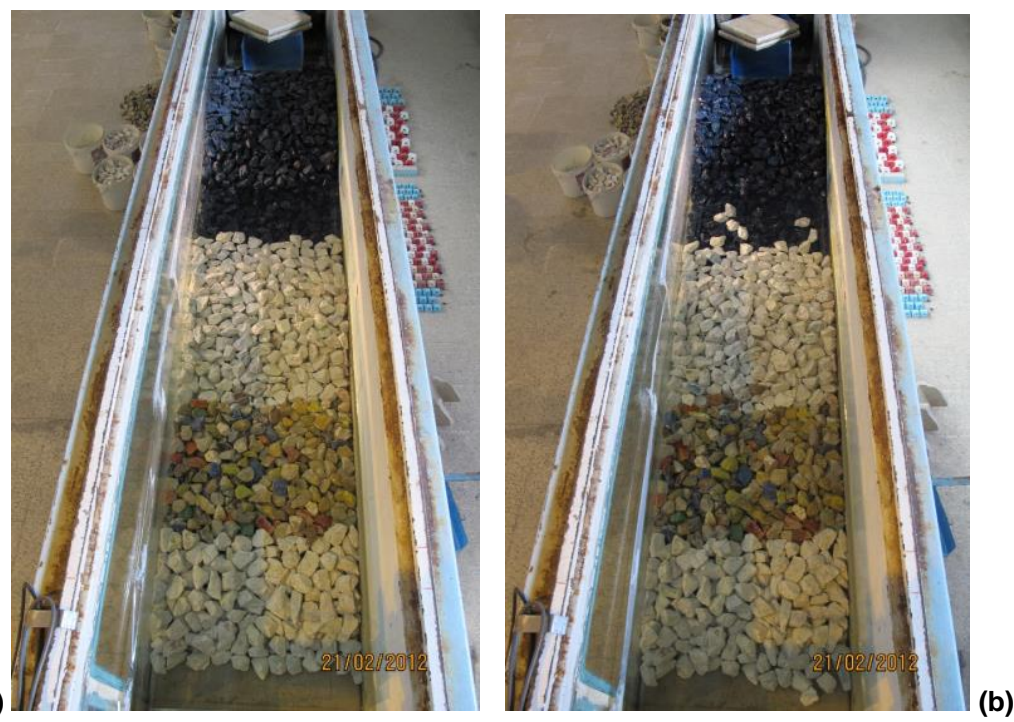

Figure A.3 (a) Before, (b) After the experiment wave set for the First Cross Section - Alternative 1

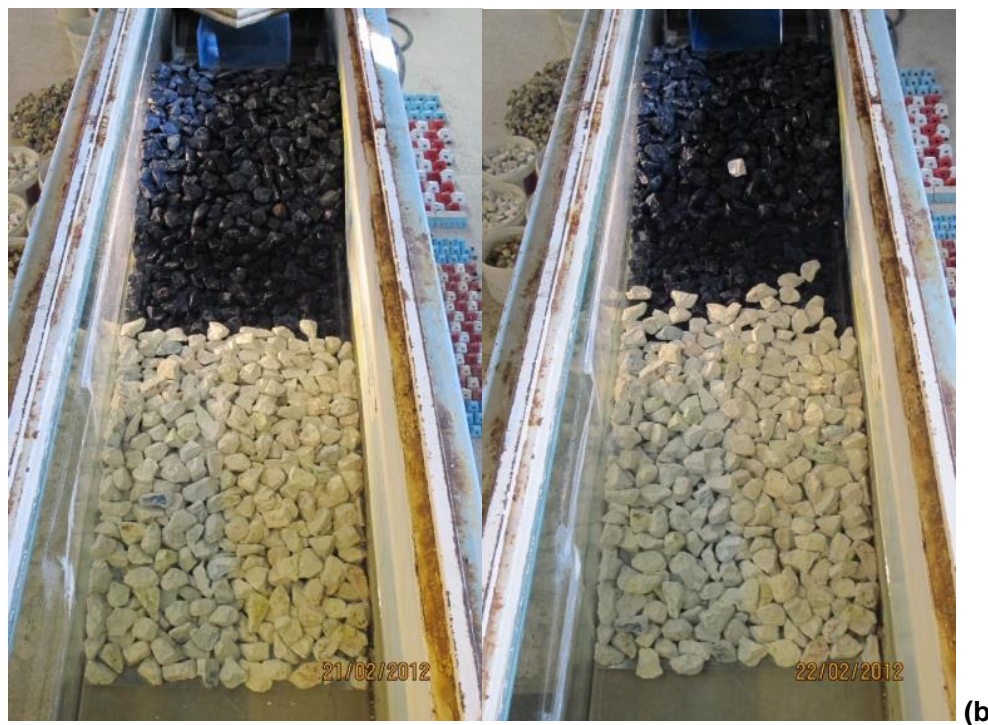

Figure A.4 (a) Before, (b) After the experiment wave set for the First Cross Section - Alternative 2
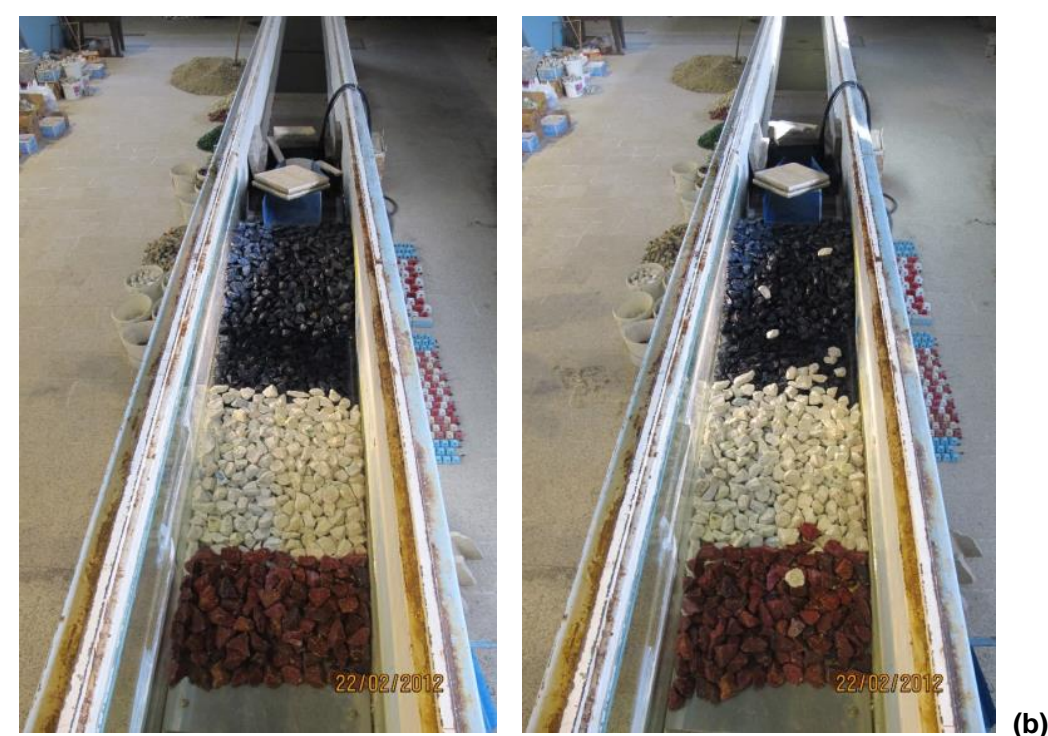

Figure A.5 (a) Before, (b) After the experiment wave set for the First Cross Section - Alternative 3 
(a)
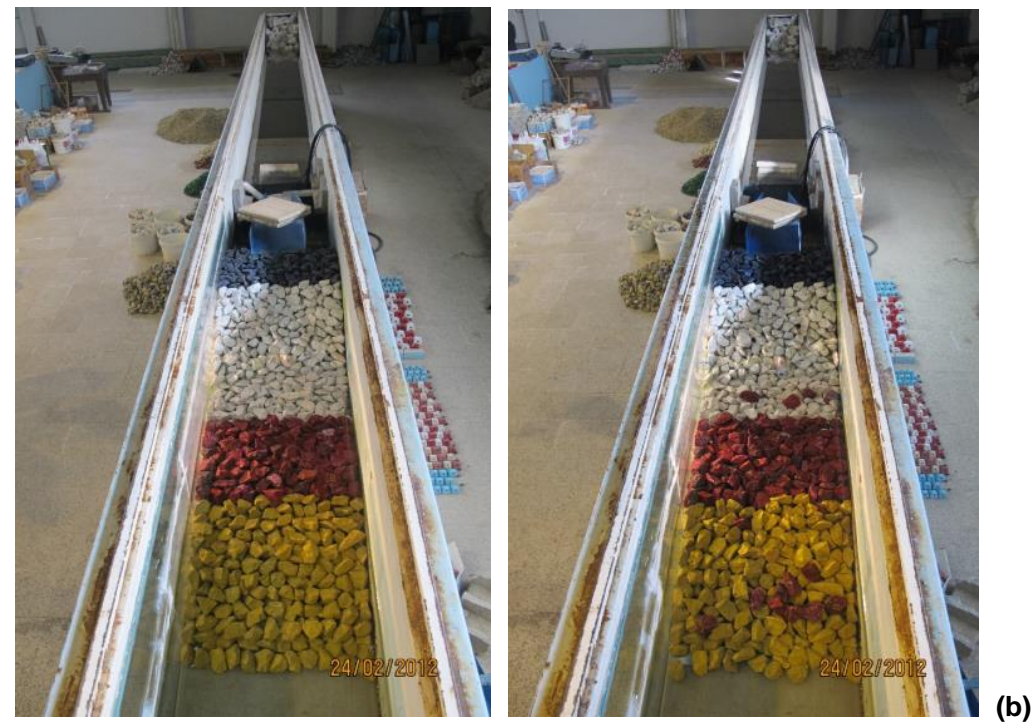

Figure A.6 (a) Before, (b) After the experiment wave set for the First Cross Section - Alternative 4
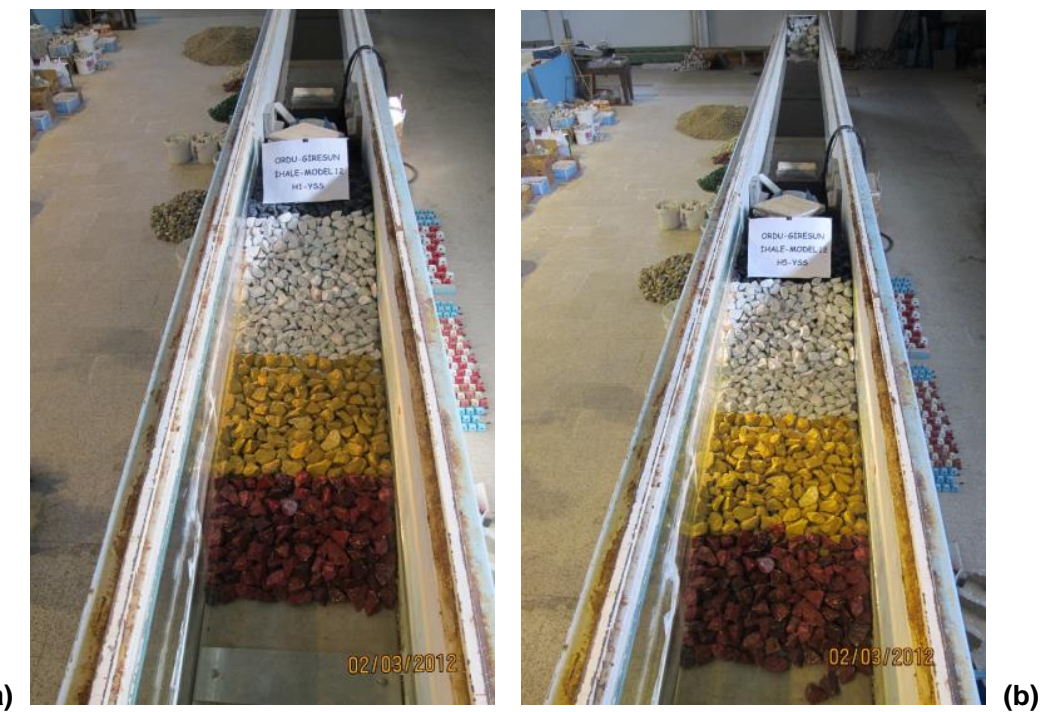

Figure A.7 (a) Before, (b) After the experiment wave set for the First Cross Section - Alternative 5
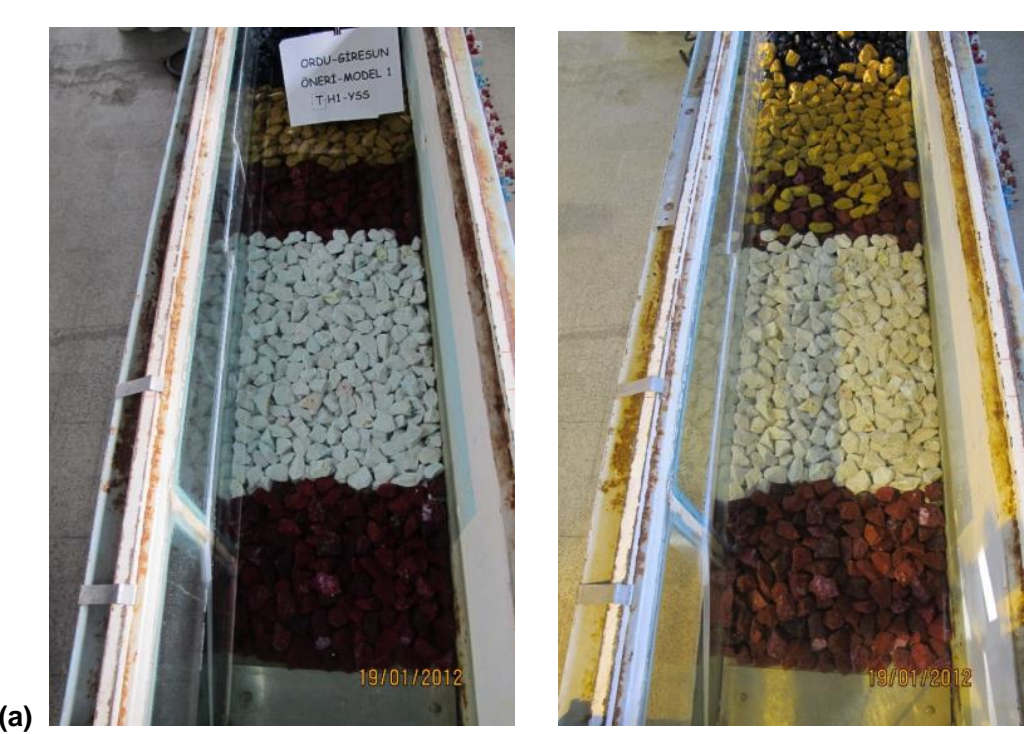

(b)

Figure A.8 (a) Before, (b) After the experiment wave set for the Second Cross Section (C Part) 
(a)
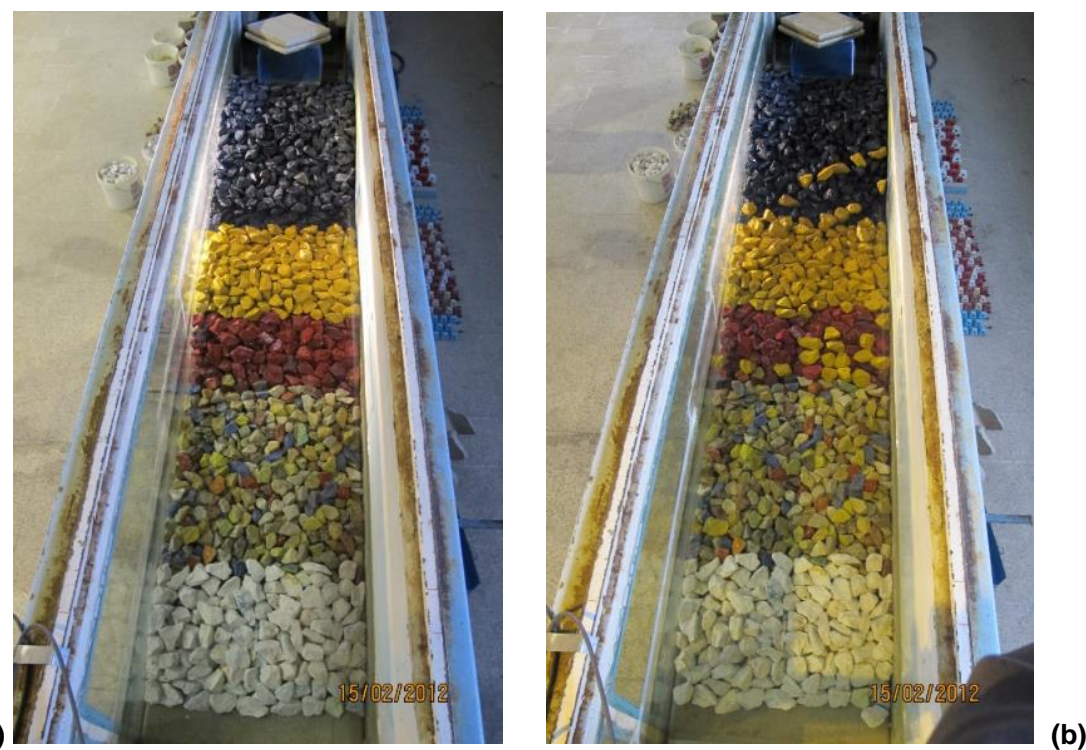

Figure A.9 (a) Before, (b) After the experiment wave set for the Second Cross Section - Alternative 1
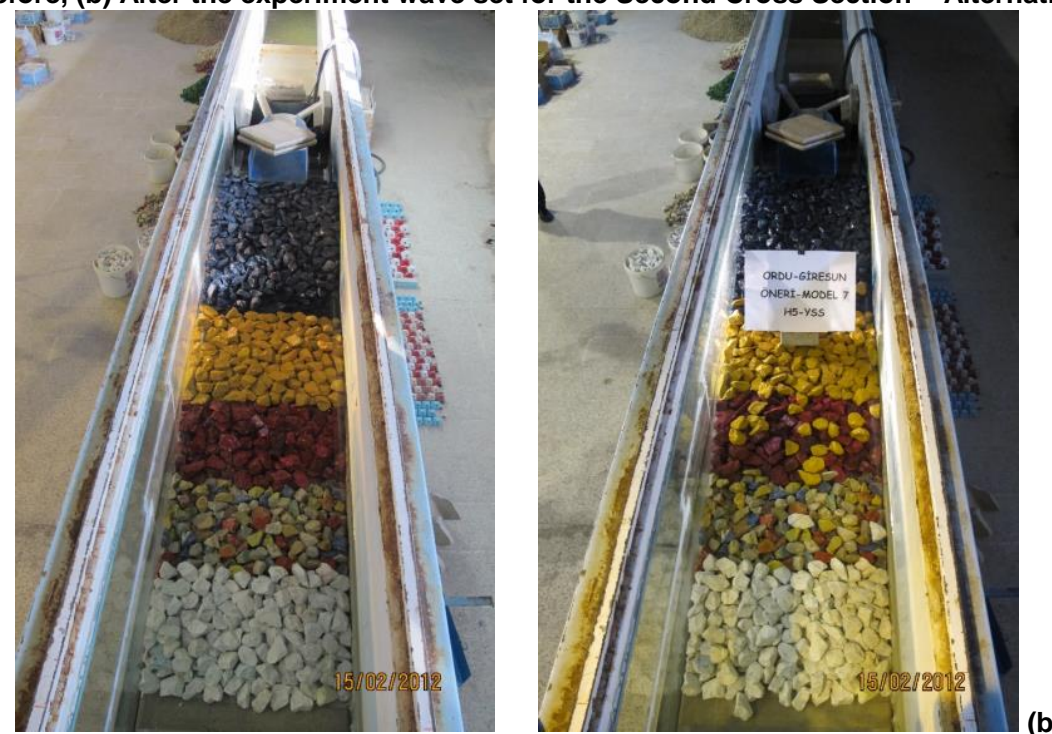

Figure A.10 (a) Before, (b) After the experiment wave set for the Second Cross Section - Alternative 2
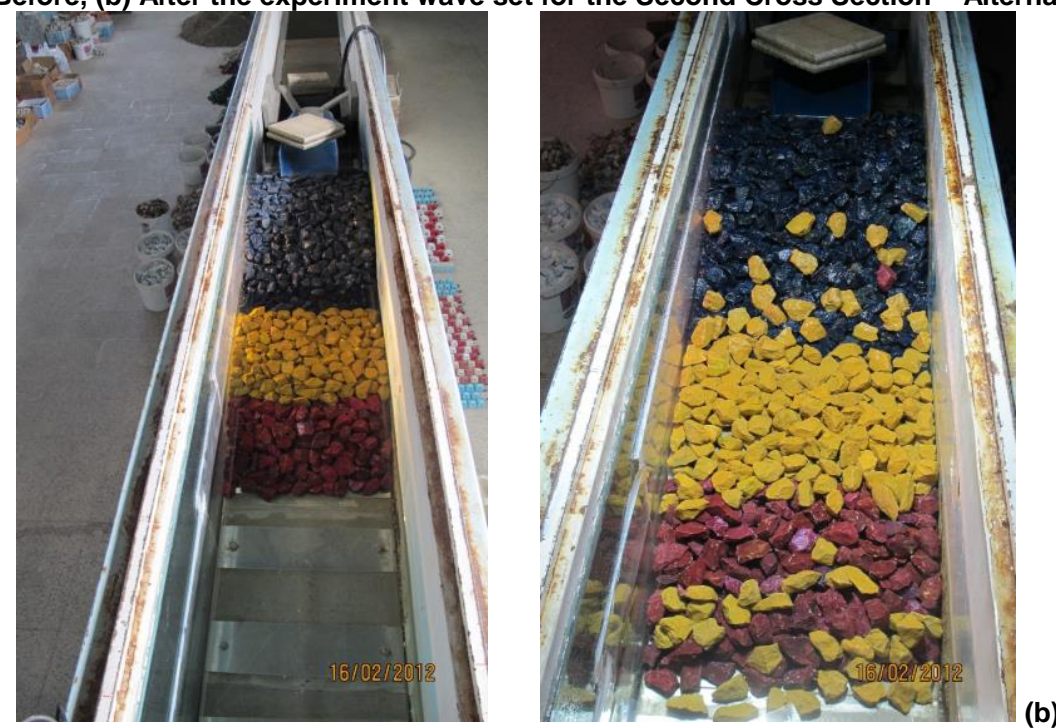

Figure A.11 (a) Before, (b) After the experiment wave set for the Second Cross Section - Alternative 3 
(a)
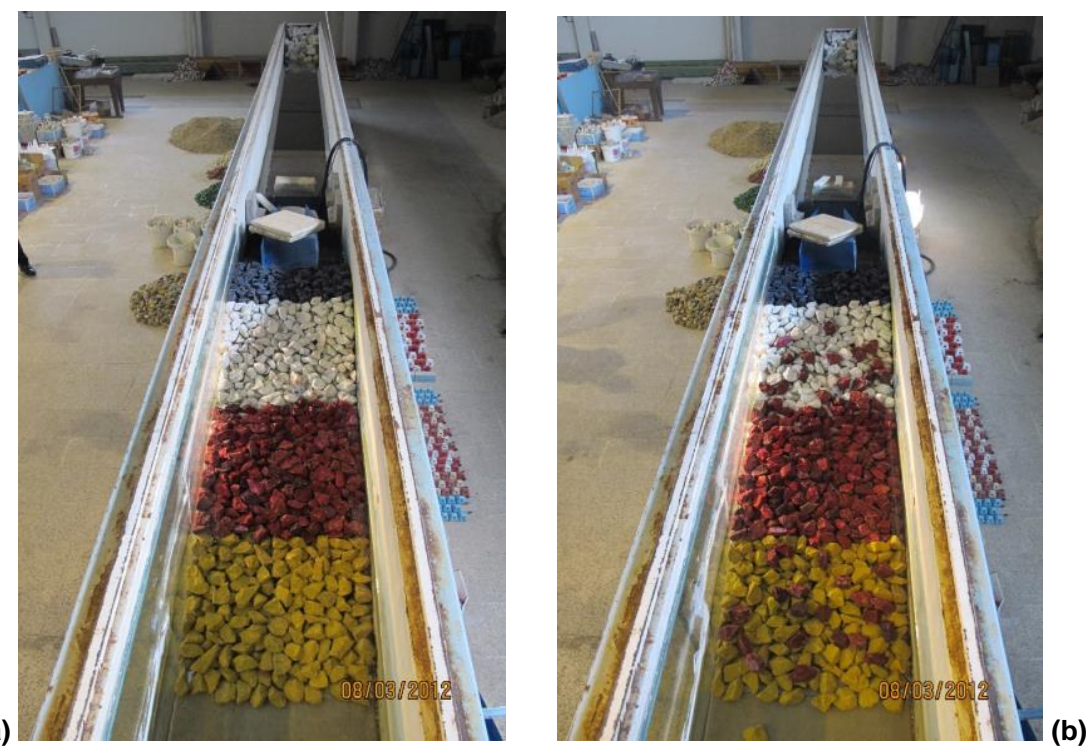

Figure A.12 (a) Before, (b) After the experiment wave set for the Second Cross Section- Alternative 4
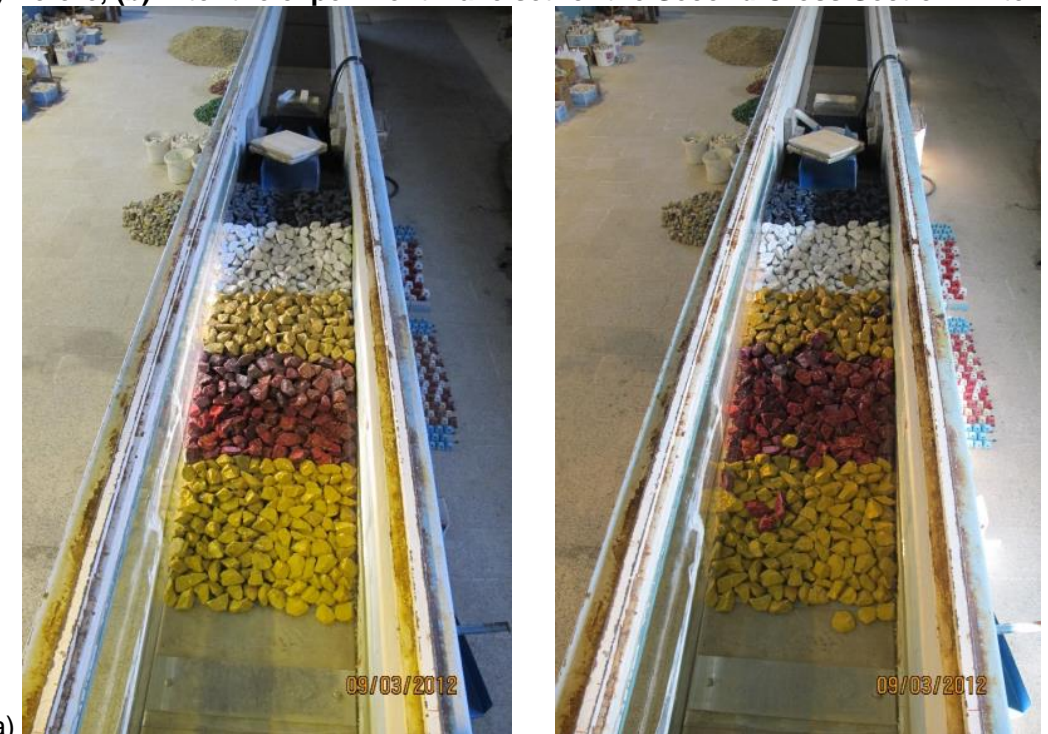

(a)

Figure A.13 (a) Before, (b) After the experiment wave set for the Second Cross Section - Alternative 5

Figure A.13 (a) Before, (b) After the experiment wave set for the Second Cross Section - Alternative 5
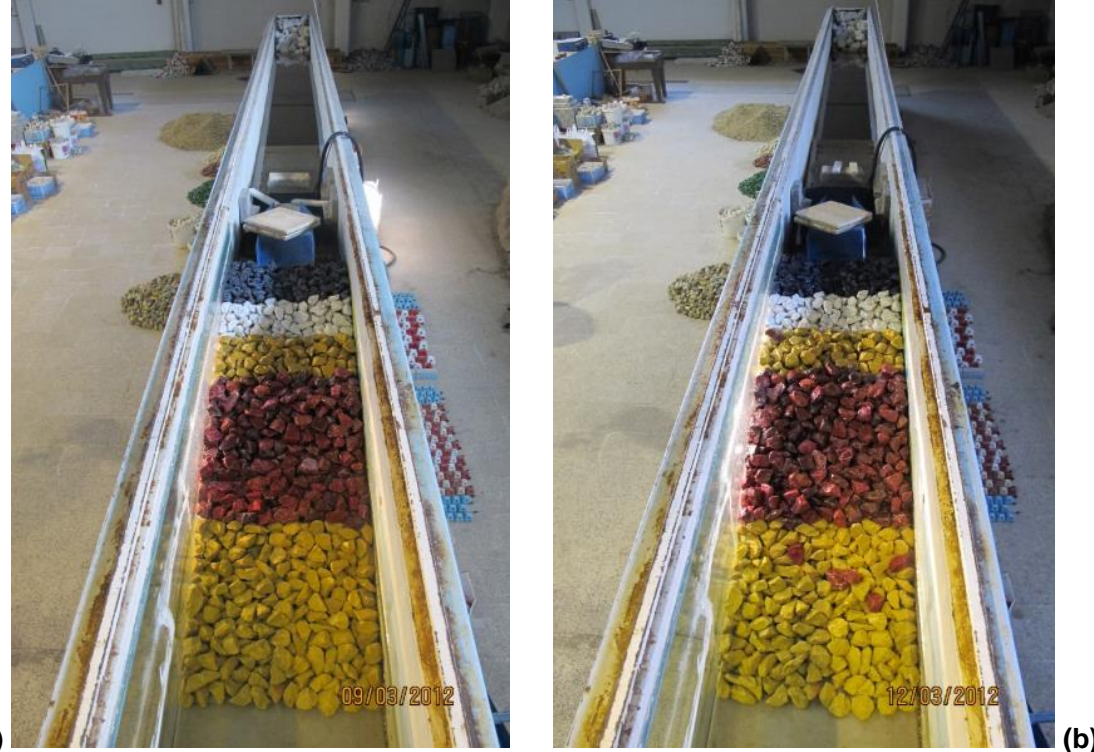

Figure A.14 (a) Before, (b) After the experiment wave set for the Second Cross Section - Alternative 6 


\section{REFERENCES}

Coastal Engineering Manual (CEM), 2003, US Army Corp, Coastal Engineering Research Center.

Google Earth, 2016. earth.google.com.

Ozhan E., Abdalla S., 2002. Turkish Coasts Deep Water Wind and Wave Atlas, Coastal Zone Management Turkish National Committee, MEDCOAST, Middle East Technical University, Ankara, Turkey.

Rock Manual (2007) The Use of Rock in Hydraulic Engineering (2nd edition) CIRIA, CUR\&CETMEF. London C683.

Report of Wind and Wave Climate Studies for Ordu-Giresun Airport Construction, 2011. Yuksel Project International A.S.

Report of Wave Transformation Studies for Ordu-Giresun Airport Construction, 2011. Yuksel Project International A.S.

Wave Overtopping Manual for Coastal Structures, 2007, p 34. 